\title{
Indefiniteness and Specificity in Old Italian Texts ${ }^{*}$
}

\author{
Elisabeth Stark \\ Universität München \\ Elisabeth.Stark@romanistik.uni-muenchen.de
}

\section{Introduction: Indefiniteness and grammaticalization of determiners: the corpus}

Object of this study is the marking of nominal indefiniteness in Old Italian, more precisely Old Tuscan texts, in three collections of novellas.

In this period of early Romance literacy, nominal Phrases $^{1}$ can appear as bare singulars or bare plurals, but also with one or more functional elements preceding the noun. The elements discussed here will be these semantically indefinite ${ }^{2}$ determiners that can appear alone with a bare noun in a NP $\left(\_N\right)$, excluding hereby indefinite elements which are only able to appear in the second (or later) position of a NP (Det_N), like certo ('certain') in Modern Standard Italian (un certo uomo, *certo uomo).

The choice of the three corpus texts has been guided by the relative homogeneity of text types, i.e. the thematic and formal continuity as testified in the anonymous Novellino (written by 1280-1300) and the ever since canonical Decameròn by Giovanni

\footnotetext{
The paper is submitted to a special issue of "Theoretical Linguistics", edited by Klaus von Heusinger and Kerstin Schwabe

1 We will not discuss here the status of the examined determiners as the head of a maximal projection, i.e. the DP-hypothesis according to Abney 1987, or the existence of a functional projection inside the DP, namely QP, cf. Löbel, E. (1989): Q as a functional category. In: Bhatt, Chr. (ed.): Syntactic Phrase Structure Phenomena in Noun Phrases and Sentences, Amsterdam/Philadelphia, 133-157. For the sake of simplicity, we will call every expression containing a noun or a pronoun a NP. We will furthermore not discuss whether the indefinite elements preceding a noun are part of the same or different syntactic categories, cf. Vater 1982 or Krifka 1989. It is highly probable that we have to distinguish elements able to be postponed or to appear separate from the noun in certain partitive constructions ("quantifier floating", for example alcuno) from elements whose position is relatively fixed (for example uno; certo is certainly on its way to an adjective-like element, being already able to cooccur with uno in our texts, though still actualizing nouns also alone. All the other elements cannot cooccur). To be able to compare their textual distribution, we only analyze the actual prenominal realizations of these elements, regardless of the fact that they can probably also appear in other positions.

2 Semantic indefinitness is to be understood in the Heimian sense as 'novelty of discourse referents' at the semantic level of 'file cards', irrespective of the actual reference of certain NPs in the text. The most important interpretation rule in 'file-change semantics' is the "Extended-Novelty-FamiliarityCondition":

"For $p$ to be felicitous w.r.t. $F$ it is required for every $\mathrm{NP}_{i}$ in $p$ that
}

(i) if $\mathrm{NP}_{\mathrm{i}}$ is [-definite], then $\mathrm{i} \notin \operatorname{Dom}(\mathrm{F})$;

(ii) if $\mathrm{NP}_{\mathrm{i}}$ is $[+$ definite], then

a) $i \in \operatorname{Dom}(\mathrm{F})$, and

b) if $\mathrm{NP}_{\mathrm{i}}$ is a formula, $\mathrm{F}$ entails $\mathrm{NP}_{\mathrm{i}}$."

(Heim 1988:369f.). In short: [+definite] means 'familiar with respect to the file', [-definite] 'novel with respect to the firle'. 
Boccaccio (the major part of the novella is written in the second half of the $14^{\text {th }}$ century) and, finally, the slightly epigonic Novellino by Masuccio Salernitano (written from 1450 to $1475 / 76$ ).

The anonymous Novellino is one of the earliest Italo-Romance narrative texts. The late $13^{\text {th }}$ century marks the relatively late beginning (in the context of Romance languages) of the Italo-Romance writing tradition and therefore represents an important turning point in the emancipation of Romance languages from Latin domination. Boccaccios Decameròn has served as a model for prose literature for centuries, in particular since Pietro Bembo in his influential Prose della volgar lingua (1525) established him, together with Petrarca for poetry, as the summit of artistic linguistic perfection in literature and marks the language variety used by Boccaccio as the obligatory variety to choose for any work of high literature in the Italo-Romance world. Even before this, Masuccio had imitated content and style of Boccaccio, although his southern Italian origins (Salerno) and a certain portion of narrative originality allow to consider his Novellino an independent work of Italian narrative.

In view of the fact that the overwhelming part of written texts in the centuries central to our study, i.e. the late $13^{\text {th }}$, the $14^{\text {th }}$ and the $15^{\text {th }}$ century, is in Latin, a language without any nominal determiners, and that Modern Italian like every Modern Romance language has definite and indefinite articles and a great variety of indefinite quantifiers and pronouns ${ }^{3}$, the main question of this discussion will be: What is the textual function of indefinite determiners in these early texts? Where do they appear at the beginning of their "grammaticalization path"4 to obligatory articles? What are the relevant semantic properties of nominal indefinite elements that determine their further development into articles, positive and negative quantifiers or "negative polarity items" ? How can modern dynamic model-theoretic semantics like DRT or "file change semantics" 6 deal with these properties and the diachronic facts, in view of the fact that the basic unit of meaning in these models is not the sentence but the (entire) discourse - the central entity when it comes to the grammaticalization of determiners (see below)? This becomes even more problematic as the semantic models in question work with a basically dichotomic conception of the semantic potential of determiners ${ }^{7}$ and consider also bare NPs (at least those containing a count noun) simply as indefinite.

\section{Emergence and Function of Nominal Determiners in Germanic and Romance Languages}

In a recent study on the development of Germanic article systems, Elisabeth Leiss (2000) considers both articles and verbal aspect markers as 'grammatical synonyms' in that they indicate 'boundedness' of objects and events, which become thereby 'percepts', 'tokens', whereas bare noun phrases or non-finite verbs tend to indicate mere concepts, 'types' ${ }^{\prime}$. The common function of aspect systems and articles is, according to

\footnotetext{
Cf. Longobardi ${ }^{3} 1991$, Renzi ${ }^{3} 1991$.

4 Cf. Hopper/Traugott 1993 und Heine/Claudi/Hünnemeyer 1991.

Cf. Hoeksema 1983, Ladusaw 1993, Ramat 1997 for Italian veruno.

Cf. Heim 1988, Kamp \& Reyle 1993.

Cf. for example the "Extended-Novelty-Familiarity-Condition" of Heim 1988 cited above.

8 Cf. the early sketch of the principal article functions in Coseriu 1955.
} 
Leiss, the indication of referentiality ${ }^{9}$, i.e. they indicate the reference of the internal verb-argument. Languages with the aspectual opposition 'perfective' - 'imperfective' can do without articles, because the mere value of 'perfective' action or event allows to conclude to the existence of a specific, determined object involved in this action or event (cf. approximately in the English example Peter has eaten an apple.), while 'imperfective' aspect favors the 'concept-status' of the intended referent (generic or non-specific: Peter used to eat an apple every day in his youth). Loss of aspectual marking is, according to Leiss, often accompanied by the gradual obligatorification ${ }^{10}$ of nominal determiners, which in the beginning cooccur preferably with count nouns in the focus of information, marking their important and new referential status as percepts (in so-called 'hypodetermining languages'). Later, (definite) articles turn to mark anaphorically known referents, i.e. given information in the background of the textual information structure ('hyperdetermining languages'). Only with real 'percepts', identifiability becomes an important property of the intended referents. In this scenario, we can notice a strong correlation between (in-)definiteness and information structure, in that nominal determiners first mark foregrounded information and in a second step acquire the textual value of 'given' - vs. 'new' information (definite vs. indefinite in a textual approach to (in-)definiteness like the one in Heim 1988, for example). Leiss is able to show this correlation for Gothic and Old High German, but its adequacy for Romance languages, all of which preserve an aspectual differentiation at least in the past tenses (simple past as perfective and 'aorist', imperfect tense as imperfective or iterative/edurative/habitual) remains to be shown.

The beginning of a systematic use of nominal determiners in late Latin texts is analyzed in detail in the seminal work by Selig 1992. Latin demonstratives, ipse and later almost exclusively ille, occur first with non-continuous discourse referents of considerable importance (protagonists, important details like objects, times, places), so that we can in a first step see a certain correspondence between the findings of Leiss and Selig: nominal determiners seem to systematically mark foregrounded information, often with postverbal internal arguments, before they spread to continuous discourse referents, changing their textual potential. Selig points out, however, that on the way to systematic grammaticalization of definite determiners as anaphoric devices and always later and neither functionally nor distributionally symmetrical to them ${ }^{11}$ indefinite determiners as cataphoric, referent-introducing signals, we have to accept an intermediate period of systematic marking of each important, individualized discourse referent, i.e. of marking of specific and highly "persistent"12 textual elements ${ }^{13}$. In this period, non-specific and generic reference may still remain unmarked, a characteristic of Leiss' 'hypodetermining languages'. From this intermediate period to the obligatory marking of each continuous discourse referent (at least in argument position ${ }^{14}$ ) by the

9 Cf. the main idea of von Heusinger 1997: the epsilon-operator as the common semantic element of definite and indefinite article serves to determine a 'representative' of a set, to form a term out of a non-fixed element of a set.

10 One characteristics of grammaticalization processes, cf. Lehmann 1985.

1 Cf. Christophersen 1939, Coseriu 1955, Moravcsik 1969, Hawkins 1978, Chesterman 1991 etc.

12 Cf. Givón, T. (1983): Topic Continuity in Discourse: An Introduction. In: Givón, T. (ed.): Topic Continuity in Discourse: A Quantitative Cross Language Study. Amsterdam/Philadelphia, 1-41.

13 Stage II in Greenbergs 1978 scheme of different stages in definiteness marking and article grammaticalization.

14 For a typological language classification according to the possibility of admitting bare noun phrases in argument position cf. Chierchia 1998. 
definite and, also, of each new (singular) discourse referent by the indefinite article, the earlier apparently fundamental distinction between specific and non-specific reference seems to get lost.

\section{Specificity and textual information structure}

The notion of specificity is fundamental to the following speaker-oriented distinction: "An indefinite $\left[{ }^{15}\right]$ singular noun phrase may be used to denote a particular entity, or to speak of any arbitrary member of the class described by the noun phrase." ${ }^{16}$ In the former case, the respective noun phrase can be interpreted specifically, whereas in the latter, it is to be interpreted non-specifically.

Regardless of the debate whether definite and/or indefinite descriptions involve reference or not, and whether reference is better to be described as a semantic or purely pragmatic phenomenon, recent accounts, both theoretical and empirical, show the relevance of specificity at a discourse pragmatic level: in modern languages possessing definite and indefinite articles ${ }^{17}$, the early stages of determiner grammaticalization systematically demonstrate a high preference to mark specific, i.e. particular important discourse elements in texts ${ }^{18}$. Speakers and writers highlight specific referents, first by certain indefinite elements, later in the text by definite determiners, searching to lend a certain profile ('foreground vs. background of the story') to their texts. Recent semantic accounts of specificity have attempted to explain the often mentioned existential presupposition of specific indefinites by '(textual) givenness' in a broad sense as the central semantic element of specific noun phrases and thereby a certain affinity of specific and definite noun phrases ${ }^{19}$. As there are special contexts which provoke a specific and others which provoke a non-specific interpretation of indefinite noun phrases $^{20}$ (sometimes there are also pragmatic reasons excluding one or the other interpretation), Haspelmath 1997 analyzes the occurrences of different series of indefinite pronouns in contexts which favor specific interpretation (concerning especially arguments of predicates aspectually marked as perfective) and in contexts which favor non-specific interpretation (especially "negative polarity contexts" like questions, the protasis in conditionals, scope of negation, "irrealis" contexts like imperatives, futures etc) ${ }^{21}$.

15 Specificity-distinctions exist also for definite noun phrases, see for further discussion Lyons 1999 , $165-178$.

16 Lyons 1999, 165.

17 See also Lyons 1999, 177f., who mentions a great variety of languages (for example of the Austronesian family) indicating both specificity and definiteness (i.e. their common feature of 'familiarity' to the speaker) by only one article.

18 Cf. the results in Skrélina /Čebelis 1972, Blazer 1979, Givón 1981, Heinz 1982, Selig 1992, Elvira 1994, Rosén 1994.

19 Cf. the short discussion of specificity in Heim 1988, 220-226; see further Enç 1991, who shows a partitive "inclusion-relation" between specific referents and a prementioned group ("weak antecedents", cf. Enç 1991, 7ff.), Delfitto/Corver 1998 who attribute a "familiarity presupposition" to specific referents which causes certain syntactic phenomena, Van Geenhoven 1998 etc.

20 Cf. for example Heim 1988, 220ff., following Fodor/Sag 1982.

21 Note that Eva Lavric, following Kleiber, shows in her publications the necessity to differentiate between 'hypothetic' (like the scope of negation, arguments of world-creating predicates etc) vs. 'factive contexts' and the opposition of 'referent known' vs. 'referent unknown' to the speaker, which 
To sum up: Besides the obvious correlation between (in-)definiteness and information structure accounted for in each textual concept of (in-)definiteness as, roughly speaking, 'given' vs. 'new information' (the basic distinction also in DRT and "file-change semantics", see above), the speaker-oriented category of specificity is also to be considered whenever one analyzes information packaging in texts. Particularly in the early stages of grammaticalization like the one discussed here with Old Italian texts, specificity seems to be a decisive factor which provokes the marking of noun phrases by determiners in general and it seems to be a feature that can be explicitly marked by lexical differentiation in the paradigm of indefinite elements (cf. Haspelmath 1997, Lyons 1999, 174ff.). The guiding question of the following account will be if a simple dichotomy 'definite' vs. 'indefinite' in the sense 'given' vs. 'new information' (or 'file card", for example) is sufficient to understand the functioning of the most frequent indefinite determiners in the texts, and also if the category of "introducing discourse referents" is adequate at all, at least at a discourse-pragmatic level, to describe certain indefinites or if it could not be precisely the signaling of 'non-introduction' that is the textual contribution of some of the analyzed indefinites. Interestingly enough, Hans Kamp (this volume) discusses precisely this problem in his proposal of a "use-oriented approach to specificity and related notions", when he asks, from the speaker's point of view, "what indefinite NP to choose" (6), if the hearer of a discourse element does not have "a representation in his entity library for the entity [...] which the speaker [...] represents" (4) by a noun phrase. Kamp mentions some contexts (for example transsentential anaphora to an indefinite) which incite a non-existential interpretation, and asks whether it could be "part of the semantics of such discourses that the indefinite gets a non-existential interpretation" (8f.). In this case, we could probably go a step further in investigating indefinite elements and show that sometimes not only their context elements, but their lexical semantics itself incites specific or non-specific interpretation.

The above mentioned correlations of (in-)definiteness and information structure lead to a detailed analysis of the following distributional characteristics of indefinite determiners: If nominal determination serves to highlight 'rhematic', foregrounded discourse referents in 'hypodetermining languages' and to mark the 'given' vs. 'new' status of the respective discourse referents in 'hyperdetermining languages' (Leiss 2000), we have to examine the sentential distribution of the occurrences of indefinites, i.e. their occurrences in pre- or postverbal position (in the main syntactic functions subject and object) and their occurrences in main vs. subordinate clauses with finite or non-finite verbs, together with their cooccurences with perfective vs. imperfective aspect (in the Romance languages in the past: passato remoto vs. imperfetto). If specificity is furthermore the main feature admitting anaphoric reference to the new referent introduced by the indefinite noun phrase in question ${ }^{22}$, and if it is in general the main motivation to mark a discourse referent (see above, especially Selig 1992), we have to discuss the cataphoric potential of the indefinite noun phrases and their ability to introduce a central discourse referent. Finally, we will search for a pattern of lexical differentiation inside the group of the discussed indefinite determiners according to

are both understood as revealing the opposition of 'specific' vs. 'non-specific'. Haspelmath provides linguistic evidence for this distinction by showing that some languages have a different series of indefinite pronouns for specific indefinites denoting referents known and those unknown to the speaker, for example in Russian, cf. Haspelmath 1997, 45-48. 
specificity vs. non-specificity and will therefore study the distribution of indefinite NPs in highly 'specific' vs. 'non-specific' contexts according to Haspelmath 1997.

\section{Properties of indefinites in Old Italian}

To understand the lexical differentiation in Old Italian indefinite determiners, we have to shed a light on Modern Standard Italian, a clearly 'hyperdetermining language' (Leiss 2000). In Modern Italian, there is a textual opposition of definite (neutrally marked by the definite article $i l$ and its allomorphs) and indefinite noun phrases, the former being either marked by the indefinite article derived from the numeral $u n o^{23}$ for singular count nouns in argument position, a partitive article $(\mathrm{del})^{24}$ for singular mass nouns in certain syntactic positions, especially in preverbal subject and in object position, and with zero or a plural partitive (dei) or alcuni ('some') or certi ('certain') with plural count nouns. Zero is in these cases always interpreted non-specifically and extremely restricted in preverbal position $^{25}$.

We will in the following concentrate on the correspondences or differences between the major indefinite nominal markers in Old and Modern Standard Italian, i.e. the distribution of uno, alcuno ${ }^{26}$ (in Modern Italian only under scope of negation in the singular meaning 'nobody', with specific indefinite interpretation 'some' only in the plural), certo ('a certain'), being an often mentioned indicator of specific interpretation and occurring (interestingly enough) also alone as a nominal determiner in Old Italian, and zero, since bare noun phrases are usually interpreted as indefinite in the above mentioned semantic theories (DRT, FCS). We have analyzed up to 200 occurrences of each of the three indefinite determiners and will discuss only the singular occurrences here, and, additionally, by a random selection of 100 occurrences of bare singular noun phrases.

Before we will have a closer look at the correlations between distributional properties of uno, alcuno, certo and zero and textual information structure, the

23 Cf. Givón 1978 and Renzi 1976.

24 Probably inherited of Gallo-Romance languages and appearing relatively late, so that it has not been considered in this study.

25 For details see Renzi ${ }^{3} 1991$. Besides this general sketch of indefinite descriptions, Modern Italian possesses a great variety of quantifiers and indefinite pronouns, which form, according to Haspelmath 1997, three major groups: qualche ('some' or 'any') for specific and to a large extend non-specific uses (occurring in contexts of specificity and in irrealis contexts, in questions, conditionals, under indirect negation, i.e. in complement sentences of negated matrix predicates, and direct negation), nessuno ('nobody') for negative contexts and questions, and a series of -unque (chiunque, qualunque, engl.: 'whoever', 'whatever' and so on) in comparatives and free-choice contexts. We will not discuss here the distribution of pronominal indefinites and further quantifiers.

26 The most frequent occurring indefinite determiner and pronoun in Old Italian texts after uno:

\begin{tabular}{|l|l|l|l|}
\hline & $\begin{array}{l}\text { Il Novellino (anonymous) } \\
(27029 \text { words, 4599 different } \\
\text { Lemmata (?)) }\end{array}$ & $\begin{array}{l}\text { Decameròn (Boccaccio) } \\
(269588 \text { words, 17646 different } \\
\text { Lemmata (?)) }\end{array}$ & $\begin{array}{l}\text { Il Novellino (Masuccio) } \\
\text { (135102 words, 14100 different } \\
\text { Lemmata (?)) }\end{array}$ \\
\hline uno det & $\begin{array}{l}193 \text { (out of 200 analyzed } \\
\text { occurrences of totally 538) }\end{array}$ & $\begin{array}{l}\mathbf{1 8 7} \text { (out of 200 analyzed } \\
\text { occurrences of totally 3116) }\end{array}$ & $\begin{array}{l}197 \text { (out of 200 analyzed } \\
\text { occurrences of totally 1388) }\end{array}$ \\
\hline alcuno det & 8 (out of totally 10 occurrences) & $\begin{array}{l}\mathbf{1 5 3} \text { (out of 200 analyzed } \\
\text { occurrences of totally 1114) }\end{array}$ & $\begin{array}{l}\text { 156 (out of 200 analyzed } \\
\text { occurrences of totally 439) }\end{array}$ \\
\hline
\end{tabular}


etymology of uno and alcuno has to be summarized. Classical Latin had a rather clearcut distribution of indefinite nominal markers ${ }^{27}$, in that quidam (not continued in the Romance languages) was predominantly used with indefinite NPs with specific interpretation, especially in subject position, while aliquis, the first part of the compositional and nowadays negative alc-uno, accompanied non-specifically interpreted indefinite noun phrases, and uno was neutral in this regard.

\subsection{Distribution of indefinite determiners in the sentence}

Discussing only the two major argumental positions in the sentence, i.e. subject and object position, and more precisely the occurrences of indefinites in preverbal position and special topicalization structures like left dislocations or hanging topics ${ }^{28}$, we can observe a rather clear distribution of the two syntactic functions:

\begin{tabular}{|l|l|l|l|l|l|l|l|l|}
\hline all texts & uno & & alcuno & & certo & & zero & \\
\hline subject & 118 & $20,45 \%$ & 32 & $11,64 \%$ & 3 & $12,50 \%$ & 11 & $3,67 \%$ \\
\hline preverb. & 162 & $28,08 \%$ & 123 & $44,73 \%$ & 8 & $33,33 \%$ & 111 & $37,00 \%$ \\
\hline prevSub & $\mathbf{4 1}$ & $\mathbf{3 4 , 7 5 \%}$ & $\mathbf{1 4}$ & $\mathbf{4 3 , 7 5 \%}$ & $\mathbf{1}$ & $\mathbf{3 3 , 3 3 \%}$ & $\mathbf{3}$ & $\mathbf{2 7 , 2 7 \%}$ \\
\hline object & 166 & $28,77 \%$ & 110 & $40,00 \%$ & 6 & $25,00 \%$ & 55 & $\mathbf{1 8 , 3 3 \%}$ \\
\hline prevObj. & $\mathbf{1 4}$ & $\mathbf{8 , 4 3 \%}$ & $\mathbf{2 8}$ & $\mathbf{2 5 , 4 5 \%}$ & $\mathbf{0}$ & $\mathbf{0 , 0 0 \%}$ & $\mathbf{1 4}$ & $\mathbf{2 5 , 4 5 \%}$ \\
\hline Topic. & 0 & $0,00 \%$ & 0 & $0,00 \%$ & 0 & $0,00 \%$ & 0 & $0,00 \%$ \\
\hline
\end{tabular}

Table 1

The two lines in bold in table 1 show the percentage of preverbal subjects and objects of all preverbal occurrences with indefinite determiners. Up to a half of all preverbal occurrences of uno, alcuno and certo $(34,75 \% ; 43,75 \% ; 33,33 \%)$ are subjects, while only $8,43 \%$ of preverbal uno, $25,45 \%$ of preverbal alcuno and $0,00 \%$ of preverbal certo are objects. Only zero shows almost no difference between subjects and objects occurring preverbally, being much more freely admitted in these positions with nonspecific or generic referents. Interestingly, zero is already quite rare with subjects in general $(3,67 \%$ of the totally 300 zero occurrences in all the three texts). None of the indefinites occurs in special topicalization structures.

These data suggests that we already deal with a 'hyperdetermining language' (Leiss 2000 ), since the great majority of indefinite subjects appears in preverbal position in our texts, and since a clear majority of indefinite objects appears in postverbal position, regardless of the informational status of 'new' of all the discourse referents concerned. Constituent order is thus no longer able to indicate information structure, indefinite determiners mark 'new' referents by their semantic potential.

\subsection{Specificity as a feature of the singular determiners}

\subsubsection{Specificity and 'zero'}

Concerning the textual information organization, Old Italian uno already seems to be especially used for the introduction of specific and important discourse referents:

27 Cf. Orlandini 1983, Mellet 1994.

28 Cf., among others, Cinque 1977 and 1979, Lambrecht 1994. 


\begin{tabular}{|c|c|c|c|c|c|c|c|c|}
\hline all texts & uno & & alcuno & & certo & & zero & \\
\hline main cl. & 353 & $61,18 \%$ & 91 & $33,09 \%$ & 12 & $50,00 \%$ & 175 & $58,33 \%$ \\
\hline finite & 442 & $76,60 \%$ & 159 & $57,82 \%$ & 16 & $66,67 \%$ & 211 & $70,33 \%$ \\
\hline perf. asp. & 245 & $42,46 \%$ & 35 & $12,73 \%$ & 10 & $41,67 \%$ & 99 & $33,00 \%$ \\
\hline cata.pot. & $\mathbf{3 0 6}$ & $\mathbf{5 3 , 0 3 \%}$ & $\mathbf{3 0}$ & $\mathbf{1 0 , 9 1 \%}$ & $\mathbf{4}$ & $\mathbf{1 6 , 6 7 \%}$ & $\mathbf{7 6}$ & $\mathbf{2 5 , 3 3 \%}$ \\
\hline cent.ref. & $\mathbf{1 4 6}$ & $\mathbf{2 5 , 3 0 \%}$ & $\mathbf{3}$ & $\mathbf{1 , 0 9 \%}$ & $\mathbf{1}$ & $\mathbf{4 , 1 7 \%}$ & $\mathbf{9}$ & $\mathbf{3 , 0 0 \%}$ \\
\hline
\end{tabular}

Table 2

If we look only at the two last lines of table 2, more than half of the occurrences of uno introduce highly persistent referents, and about a quarter introduce protagonists, central objects, places and so on, whereas the other determiners are relatively rare in these functions. The only slight exception is represented by zero, which accompanies discourse referents with a certain cataphoric potential $(25,33 \%)$ - a fact that is partly explained by its generic value:

\begin{tabular}{|c|c|c|c|l|c|c|c|c|}
\hline & uno & & alcuno & & certo & & zero & \\
\hline Nov. & 193 & & 8 & & 4 & & 100 & \\
\hline gen. & & & & & & & 39 & $39,00 \%$ \\
\hline & uno & & alcuno & & certo & & zero & \\
\hline Dec. & 187 & & 139 & & 10 & & 100 & \\
\hline gen. & & & & & & & 7 & $7,00 \%$ \\
\hline & uno & & alcuno & & certo & & zero & \\
\hline Mas. & 197 & & 128 & & 10 & & 100 & \\
\hline gen. & & & & & & & 3 & $3,00 \%$ \\
\hline
\end{tabular}

Table 3

Besides these clearly generic cases, there are many other occurrences of bare noun phrases which cannot be grouped without problems under the heading of 'generic', even sometimes not under 'indefinite':

(1) Marato standosi sopra la poppa e verso il mare riguardando, di niuna cosa da lor guardandosi, di concordia andarono e, lui prestamente di dietro preso, il gittarono in mare; e prima per ispazio di più d' un miglio dilungati furono, che alcuno si fosse pure avveduto Marato esser caduto in mare.

'While Marato was standing at the stern and looking towards the sea, not bothering about them, they all went together towards him and, after quickly having seized him from behind, they threw him into the sea, and they were more than one mile away when somebody realized that Marato had fallen in the sea.'

(Boccaccio, Decameron: 127)

Mare in the prepositional phrase in mare refers not only to a uniquely identifiable discourse referent in this context, but also to an already mentioned, i.e. textually given one. It refers back to a definite noun phrase ( $e$ verso il mare riguardando) and forward to another bare noun phrase (in mare). Zero in locative PPs is a rather common feature of early stages of article grammaticalization and is still preserved in Modern Standard Italian, especially with the preposition ${ }^{29} \mathrm{in}$. Contrary to the normally non-referential or better 'non-actualized' ${ }^{30}$ or generic use of noun phrases in Modern Standard Italian, our

29 Cf. Renzi ${ }^{3} 1991,412$. Renzi classifies these cases under 'non-referential', which becomes problematical in sentences with clear perfective aspect: Poi andarono in teatro ('Then they went to the theatre').

30 Cf. Coseriu 1955. 
texts show a rather systematic differentiation between PPs with important locations for the ongoing story (normally with indefinite or definite determiners) and peripherical ones $^{31}$ like in example (1), where the fact of Marato's being thrown in the water is sufficient regardless of the identification of the concerned sea. This is an example of the difficulties in analyzing bare noun phrases simply as indefinite (or generic): it is neither the mere concept of 'seahood' nor a new discourse referent in the above passage, but an unimportant one.

\subsubsection{Certo vs. alcuno - From non-specificity to negativity}

Analyzing the presumed specificity of certo and the possible non-specificity of alcuno, given its etymology (see above), we can observe a gradual specialization of these two elements on 'specific' vs. 'non-specific contexts' from the $15^{\text {th }}$ century (Decameròn) to the $16^{\text {th }}$ century (Novellino of Masuccio):

\begin{tabular}{|c|c|c|c|c|c|c|c|c|}
\hline & uno & & alcuno & & certo & & zero & \\
\hline Dec. & 187 & & 139 & & 10 & & 100 & \\
\hline main cl. & $\mathbf{9 6}$ & $\mathbf{5 1 , 3 4 \%}$ & $\mathbf{5 8}$ & $\mathbf{4 1 , 7 3 \%}$ & $\mathbf{3}$ & $\mathbf{3 0 , 0 0 \%}$ & $\mathbf{5 8}$ & $\mathbf{5 8 , 0 0 \%}$ \\
\hline finite & $\mathbf{1 2 8}$ & $\mathbf{6 8 , 4 5 \%}$ & $\mathbf{8 0}$ & $\mathbf{5 7 , 5 5 \%}$ & $\mathbf{4}$ & $\mathbf{4 0 , 0 0 \%}$ & $\mathbf{6 8}$ & $\mathbf{6 8 , 0 0 \%}$ \\
\hline perf. asp. & $\mathbf{6 6}$ & $\mathbf{3 5 , 2 9 \%}$ & $\mathbf{2 8}$ & $\mathbf{2 0 , 1 4 \%}$ & $\mathbf{3}$ & $\mathbf{3 0 , 0 0 \%}$ & $\mathbf{3 3}$ & $\mathbf{3 3 , 0 0 \%}$ \\
\hline cata.pot. & 105 & $56,15 \%$ & 12 & $8,63 \%$ & 3 & $30,00 \%$ & 23 & $23,00 \%$ \\
\hline cent.ref. & 62 & $33,16 \%$ & 2 & $1,44 \%$ & 0 & $0,00 \%$ & 1 & $1,00 \%$ \\
\hline
\end{tabular}

Table 4

\begin{tabular}{|c|c|c|c|c|c|c|c|c|}
\hline & lino & & alcuno & & certo & & zero & \\
\hline Mas. & 197 & & 128 & & 10 & & 100 & \\
\hline main cl. & $\mathbf{9 9}$ & $\mathbf{5 0 , 2 5 \%}$ & $\mathbf{2 9}$ & $\mathbf{2 2 , 6 6 \%}$ & $\mathbf{7}$ & $\mathbf{7 0 , 0 0 \%}$ & $\mathbf{4 8}$ & $\mathbf{4 8 , 0 0 \%}$ \\
\hline finite & $\mathbf{1 3 5}$ & $\mathbf{6 8 , 5 3 \%}$ & $\mathbf{7 1}$ & $\mathbf{5 5 , 4 7 \%}$ & $\mathbf{8}$ & $\mathbf{8 0 , 0 0 \%}$ & $\mathbf{6 3}$ & $\mathbf{6 3 , 0 0 \%}$ \\
\hline perf. asp. & $\mathbf{6 3}$ & $\mathbf{3 1 , 9 8 \%}$ & $\mathbf{7}$ & $\mathbf{5 , 4 7 \%}$ & $\mathbf{5}$ & $\mathbf{5 0 , 0 0 \%}$ & $\mathbf{2 7}$ & $\mathbf{2 7 , 0 0 \%}$ \\
\hline cata.pot. & 99 & $50,25 \%$ & 16 & $12,50 \%$ & 1 & $10,00 \%$ & 14 & $14,00 \%$ \\
\hline cent.ref. & 44 & $22,34 \%$ & 1 & $0,78 \%$ & 1 & $10,00 \%$ & 1 & $1,00 \%$ \\
\hline
\end{tabular}

Table 5

In the Decameròn (table 4), uno and zero appear with more than half of their occurrences in main clauses, as arguments or adjuncts of finite verb phrases and slightly more often in the scope of a perfectively marked verb. Alcuno and certo (with very few occurrences in all the three texts, so that the statistics have mere indicative value), however, do not differ very much from this behavior, except perhaps in the interesting detail that alcuno cooccurs only in $20,14 \%$ of its singular occurrences with perfective aspect.

While all indefinites analyzed still mainly occur with finite verbs, we find a clearer picture in Masuccio (table 5) when it comes to the distribution according to textual foreor backgrounding. Uno and certo are now by far the most important referentintroducing devices in main clauses, while only a fifth of alcuno's occurrences $(22,66 \%)$ is found in these contexts. Together with the finding that perfective aspect in the past marks the main 'story line' in (Romance) narrative texts, alcuno's 5,47\% of occurrences with perfectively marked verbs indicate its specialization on background information.

31 Cf. Stark (in press). 
If we have now a closer look at the 'non-specific contexts' (see above), we can observe a continuous loss of the initial non-hypothetical, but non-specific interpretations of alcuno $^{32}$ and its drift towards negative contexts - modern alcuno in the singular almost exclusively occurs in the scope of sentential negation ${ }^{33}$ :

\begin{tabular}{|c|c|c|c|c|c|c|c|c|}
\hline & uno & & alcuno & & certo & & zero & \\
\hline Nov. & 193 & & 8 & & 4 & & 100 & \\
\hline neg. & $\mathbf{1}$ & $\mathbf{0 , 5 2 \%}$ & $\mathbf{0}$ & $\mathbf{0 , 0 0 \%}$ & $\mathbf{0}$ & $\mathbf{0 , 0 0 \%}$ & $\mathbf{0}$ & $\mathbf{0 , 0 0 \%}$ \\
\hline question & 1 & $0,52 \%$ & 0 & $0,00 \%$ & 0 & $0,00 \%$ & 2 & $2,00 \%$ \\
\hline protasis & 4 & $2,07 \%$ & 2 & $25,00 \%$ & 1 & $0,00 \%$ & 3 & $3,00 \%$ \\
\hline irr. con. & 11 & $5,70 \%$ & 2 & $25,00 \%$ & 1 & $25,00 \%$ & 6 & $6,00 \%$ \\
\hline perf. & $\mathbf{1 1 6}$ & $\mathbf{6 0 , 1 0 \%}$ & $\mathbf{0}$ & $\mathbf{0 , 0 0 \%}$ & $\mathbf{2}$ & $\mathbf{5 0 , 0 0 \%}$ & $\mathbf{4 0}$ & $\mathbf{4 0 , 0 0 \%}$ \\
\hline
\end{tabular}

Table 6

\begin{tabular}{|c|c|c|c|c|c|c|c|c|}
\hline & uno & & alcuno & & certo & & zero & \\
\hline Dec. & 187 & & 139 & & 10 & & 100 & \\
\hline neg. & $\mathbf{4}$ & $\mathbf{2 , 1 4 \%}$ & $\mathbf{3 4}$ & $\mathbf{2 4 , 4 6 \%}$ & $\mathbf{0}$ & $\mathbf{0 , 0 0} \%$ & $\mathbf{1 7}$ & $\mathbf{1 7 , 0 0 \%}$ \\
\hline question & 2 & $1,07 \%$ & 10 & $7,19 \%$ & 0 & $0,00 \%$ & 2 & $2,00 \%$ \\
\hline protasis & 3 & $1,60 \%$ & 5 & $3,60 \%$ & 0 & $0,00 \%$ & 0 & $0,00 \%$ \\
\hline irr. con. & 21 & $11,23 \%$ & 28 & $20,14 \%$ & 0 & $0,00 \%$ & 12 & $12,00 \%$ \\
\hline perf. & $\mathbf{6 6}$ & $\mathbf{3 5 , 2 9 \%}$ & $\mathbf{2 7}$ & $\mathbf{1 9 , 4 2 \%}$ & $\mathbf{3}$ & $\mathbf{3 0 , 0 0 \%}$ & $\mathbf{3 3}$ & $\mathbf{3 3 , 0 0 \%}$ \\
\hline
\end{tabular}

Table 7

\begin{tabular}{|c|c|c|c|c|c|c|c|c|}
\hline & uno & & alcuno & & certo & & zero & \\
\hline Mas. & 197 & & 128 & & 10 & & 100 & \\
\hline neg. & $\mathbf{4}$ & $\mathbf{2 , 0 3 \%}$ & $\mathbf{4 6}$ & $\mathbf{3 5 , 9 4 \%}$ & $\mathbf{0}$ & $\mathbf{0 , 0 0 \%}$ & $\mathbf{4}$ & $\mathbf{4 , 0 0 \%}$ \\
\hline question & 0 & $0,00 \%$ & 5 & $3,91 \%$ & 0 & $0,00 \%$ & 2 & $2,00 \%$ \\
\hline protasis & 1 & $0,51 \%$ & 8 & $6,25 \%$ & 0 & $0,00 \%$ & 0 & $0,00 \%$ \\
\hline irr. con. & 31 & $15,74 \%$ & 25 & $19,53 \%$ & 1 & $10,00 \%$ & 11 & $11,00 \%$ \\
\hline perf. & $\mathbf{6 3}$ & $\mathbf{3 1 , 9 8 \%}$ & $\mathbf{7}$ & $\mathbf{5 , 4 7 \%}$ & $\mathbf{5}$ & $\mathbf{5 0 , 0 0 \%}$ & $\mathbf{2 7}$ & $\mathbf{2 7 , 0 0 \%}$ \\
\hline
\end{tabular}

Table 8

Considering only two criteria, cooccurrence with sentential negation on the one hand and perfective aspect on the other, we can see an important development from the almost archaic anonymous Novellino in the late $13^{\text {th }}$ century (table 6) with generally very little lexical variation in the field of nominal indefiniteness and a systematic marking of highly important specific discourse referents by uno in the foreground of the single novellas, regardless of negation. Boccaccio's Decameròn (table 7) shows one of the most varied paradigms of indefinite determiners (and pronouns) in our corpus. It demonstrates the obvious 'specificity opposition' of uno vs. alcuno, the former appearing rarely in negative or negative polarity contexts (and occurring with important discourse referents, as demonstrated above), the latter still appearing in foregrounded portions of the text (with perfective aspect), but occurring already more often particularly in negative contexts. The latest text, Masuccios Novellino (table 8), shows a strengthening of this development towards Modern Standard Italian, with more than a third of the alcuno-occurrences in negative contexts.

\footnotetext{
32 See above, footnote 21 , for the distinction between hypothetical and non-specific, i.e. not known to the speaker.

3.3 Cf. Ramat 1997 for the parallel, but earlier development of veruno.
} 


\subsubsection{Lexical differentiation}

A synopsis of all the three texts shows that uno and certo are definitely the Old Italian determiners in the textual foreground (compare also the findings for textual persistency of discourse referents introduced by uno and certo in table 2), uno having almost lost the etymological potential of being neutral with respect to specificity oppositions:

\begin{tabular}{|c|c|c|c|c|c|c|c|c|}
\hline all texts & uno & & alcuno & & certo & & zero & \\
\hline negation & 9 & $1,56 \%$ & 80 & $29,09 \%$ & 0 & $0,00 \%$ & 21 & $7,00 \%$ \\
\hline question & 3 & $0,52 \%$ & 15 & $5,45 \%$ & 0 & $0,00 \%$ & 6 & $2,00 \%$ \\
\hline protasis & 8 & $1,39 \%$ & 15 & $5,45 \%$ & 1 & $4,17 \%$ & 3 & $1,00 \%$ \\
\hline irr. con. & 63 & $10,92 \%$ & 55 & $20,00 \%$ & 2 & $8,33 \%$ & 29 & $9,67 \%$ \\
\hline perf. & $\mathbf{2 4 5}$ & $\mathbf{4 2 , 4 6 \%}$ & $\mathbf{3 4}$ & $\mathbf{1 2 , 3 6 \%}$ & $\mathbf{1 0}$ & $\mathbf{4 1 , 6 7 \%}$ & $\mathbf{1 0 0}$ & $\mathbf{3 3 , 3 3 \%}$ \\
\hline gen. & & & & & & & 49 & $16,33 \%$ \\
\hline
\end{tabular}

Table 9

For an impressive example of the almost complementary distribution of uno and alcuno with respect to 'specificity' contexts, see the following example:

$$
\begin{aligned}
& \text { I due fratelli, come che molta speranza non prendessono di questo, nondimeno } \\
& \text { se n' andarono a una religione di frati e domandarono alcuno santo e savio } \\
& \text { uomo che udisse la confessione d' un lombardo che in casa loro era infermo; } e \\
& \text { fu lor dato un frate antico di santa e di buona vita e gran maestro in Iscrittura e } \\
& \text { molto venerabile uomo, nel quale tutti i cittadini grandissima e speziale } \\
& \text { divozione aveano, e lui menarono. } \\
& \text { 'The two brothers, although they did not have much hope from this, went to a } \\
& \text { monastery and asked for a holy and wise man who could hear the confession of a } \\
& \text { Lombardian who was in their house, sick, and they were given an old monk of } \\
& \text { holy and good life and a great master of the Holy Bible and a very venerable } \\
& \text { man, who was devotionally honored by all the citizens, and they took him with } \\
& \text { them.' }
\end{aligned}
$$

(Boccaccio, Decameron: 30 )

The internal argument of the 'world-creating predicate' domandare ('to ask for') without existential presupposition is introduced by alcuno, indicating clearly the nonfactual status of this discourse referent. Only when the semantics of the main predicate ( $\mathrm{fu}$ lor dato - 'they were given') implies the existence of its internal argument (still postverbal in our example and with very similar lexical material) and when the noun phrase in question introduces an important discourse referent (in this case one of the protagonists), the 'real' referent-introduction is done by uno. Even if this example provides further evidence for the variable-analysis of indefinites, bound by (existential) operators (here inside the $\mathrm{VP}^{34}$ ), we want to point out that in Old Italian texts there is very little ambiguity as to the opposition between specific or non-specific interpretation of indefinite noun phrases - Old Italian writers knew "what indefinite to choose" (see the quotation from Kamp, above).

34 Cf. among others Carlson 1977, Heim 1988, Van Geenhoven 1998. 


\section{Conclusion}

A close examination of the textual distribution of the four main Old Italian indefinite determiners uno, alcuno, certo and zero in singular noun phrases in three collections of novellas with respect to 'specific' vs. 'non-specific' contexts and sentential and textual information organization, revealed a rather clear-cut lexical differentiation in Old Italian. Uno and certo occur preferably with important text referents, while alcuno is non-specific (hypothetical) and only slowly acquiring its modern negative value. The function of zero resists any simple classification as 'indefinite', i.e. referent-introducing, being much more common also in the singular than in Modern Italian and having several values (generic, non-referential, non-specific etc.).

Finally, the most astonishing finding is the loss of 'neutrality' of Latin unus according to the specific - non-specific opposition in Old Italian. Here, the whole paradigm of the main indefinite determiners allows to treat specificity or non-specificity as a lexical feature of elements. From there on, however, we assist a gradual spread of uno also to non-specific contexts from the $14^{\text {th }}$ century to contemporary Standard Italian (cf. tables 6 to 8; simultaneously, alcuno is restricted to negative contexts, zero to nonreferential ones, and certo loses its status as a determiner), where the two possible interpretations of uno in ambiguous, particularly in opaque contexts, can be indeed discussed as a matter of $\operatorname{syntax}^{35}$ or even pragmatics ${ }^{36}$.

\section{References}

\section{Corpus:}

Anonymous [1300] (1970): Il Novellino. Ed. by G. Favati. Genua.

Boccaccio, G. [1370] (1976): Decameron. Critical edition after the Hamilton Manuscript, ed. by V. Branca. Florence.

Salernitano, M. (1957): Il Novellino. Ed. by G. Petrocchi. Florence.

\section{2.}

Bickerton, D. (1981): Roots of Language. Ann Arbor.

Blazer, E. D. (1979): The Historical Development of Articles in Old French. Diss. University of Texas at Austin, Austin/Texas.

Blïcher, K. (1974): Studie sulle forme ho cantato cantai, cantavo, stavo cantando. Oslo.

Carlson, G. N. (1977): Reference to Kinds in English. Doctoral Dissertation, University of Massachussetts, Amherst. Published 1980. New York: Garland.

Chafe, W. L. (1976): Givenness, Contrastiveness, Definiteness, Subjects, Topics and Point of View. In: Li, Ch. N. (ed.): Subject and Topic. New York, 25-55.

Chesterman, A. (1991): On Definiteness. A Study with Special Reference to English and Finnish. Cambridge.

Chierchia, G. (1998): Reference to Kinds across Languages. In: Natural Language Semantics 6-4, 339405.

Christophersen, P. (1939): The Articles: A Study of Their Theory and Use in English. Kopenhagen.

Cinque, G. (1977): The Movement Nature of Left Dislocation. In: Linguistic Inquiry 8-2, 397-412.

Cinque, G. (1979): Left-Dislocation in Italian: A Syntactic and Pragmatic Analysis. In: Cahiers de lexicologie 34-1, 96-127.

Combettes, B. (1987): Marqueurs de généricité et ordre des mots: article défini et déterminant zéro en moyen-français. In: Kleiber, G. (ed.): Rencontre(s) avec la généricité. Metz, 9-32.

35 Cf. for example Diesing 1992.

36 Cf. for example Groenendijk/Stokhof 1981, Ludlow/Neale 1991. 
Coseriu, E. (1955): Determinación y entorno. Dos problemas de una lingüistica del hablar. In: Romanistisches Jahrbuch 7, 29-54.

Delfitto, D. ; Corver, N. (1998): Feature Primitives and the Syntax of Specificity. In: Rivista di Linguistica 10-2, 281-334.

Diesing, M. (1992): Indefinites. Cambridge/Mass.

Elvira, J. (1994): Un(o) en español antiguo. In: Verba 21, 167-182.

Enç, M. (1991): The Semantics of Specificity. In: Linguistic Inquiry 22-1, 1-25.

Faingold, E. D. (1994): The Genesis of the Article System in Creolization and Historical Change In: Papiere zur Linguistik 50-1, 51-63.

Fodor, J. D. ; Sag, I. A. (1982): Referential and Quantificational Indefinites. In: Linguistics and Philosophy 5, 355-398.

Givón, T. (1978): Definiteness and Referentiality. In: Greenberg, J. (ed.): Universals of Human Language. Vol IV: Syntax. Stanford, 291-330.

Givón, T. (1981): On the development of one as an indefinite marker. In: Folia Linguistica Historica II, 35-53.

Givón, T. (1983): Topic Continuity in Discourse: An Introduction. In: Givón, T. (ed.): Topic Continuity in Discourse: A Quantitative Cross Language Study. Amsterdam/Philadelphia, 1-41.

Greenberg, J. H. (1978): How Does a Language Acquire Gender Markers? In: Greenberg, J. H. (ed.): Universals of Human Language. Vol. III. Stanford, 47-82.

Groenendijk, J. ; Stokhof, M. (1981): A Pragmatic Analysis of Specificity. In: Heny, F. (ed.): Ambiguities in Intensional Contexts. Dordrecht, 153-190.

Gundel, J. K. (1977): The Role of Topic and Comment in Linguistic Theory. Austin.

Haspelmath, M. (1997): Indefinite Pronouns. Oxford.

Hawkins, J. A. (1978): Definiteness and Indefiniteness. A Study in Reference and Grammaticality Prediction. London.

Heim, I. (1988).: The Semantics of Definite and Indefinite Noun Phrases. New York.

Heine, B. ; Claudi, U. ; Hünnemeyer, F. (1991): Grammaticalization. A Conceptual Framework. Chicago.

Heinz, S. (1982): Determination und Re-präsentation im Altfranzösischen. München.

Hoeksema, J. (1983): Negative Polarity and the Comparative. In: Natural Language and Linguistic Theory 1, 403-434.

Hopper, P. J. / Traugott, E. C. (1993): Grammaticalization. Cambridge.

Jacobs, J. (1988): Fokus-Hintergrund-Gliederung und Grammatik In: Altmann, H. (ed.): Intonationsforschungen. Tübingen, 89-134.

Kamp, H. / Reyle, U. (1993): From Discourse to Logic. Introduction to Model-theoretic Semantics of Natural Language, Formal Logic and Discourse Representation Theory. Dordrecht.

Karttunen, L. (1969, reprint 1976): Discourse Referents. In: McCawley, J. D. (ed.); Syntax and Semantics 7. New York u.a., 364-384.

Kiss, K. É. (1995): On Generic and Existential Bare Plurals and the Classification of Predicates. In: Rothstein, S. (ed.): Events and Grammar. London, 145-162.

Krifka, M. (1989): Nominalreferenz und Zeitkonstitution. Zur Semantik von Massentermen, Pluraltermen und Aspektklassen. München.

Ladusaw, W. A. (1993): Negation, Indefinites, and the Jespersen Cycle. In: Proceedings of the Nineteenth Annual Meeting of the Berkeley Linguistics Society (Ferbruary 12-15, 1993), 437-446.

Lambrecht, K. (1994): Information Structure and Sentence form. Topic, Focus, and the Mental Representations of Discourse Referents. Cambridge.

Lavric, E. (1990): Mißverstehen verstehen: Opake Kontexte und Ambiguitäten bei indefiniten und definiten Nominalphrasen. Graz.

Lavric, E. (2000): Ein Modell der Referenz determinierter Nominalphrasen. In: Zeitschrift für romanische Philologie 116-1, 20-55.

Lehmann, Chr. (1985): Synchronic Variation and Diachronic Change. In: Lingua e stile 20-3, 303-318.

Leiss, E. (2000): Artikel und Aspekt. Die grammatischen Muster von Definitheit. Berlin - New York.

Longobardi, G. ("1991): I quantificatori. In: Renzi, L. (ed.): Grande grammatica italiana di consultazione. Vol. I: La frase. I sintagmi nominale e preposizionale. Bologna, 645-696.

Ludlow, P. ; Neale, S. (1991): Indefinite Descriptions in Defense of Russell. In: Linguistics and Philosophy 14, 171-202.

Lyons, Chr. (1999): Definiteness. Cambridge.

Mellet, S. (1994): Classes d'occurrences et construction référentielle en latin. In: L'Indéfini. Paris, 49-56.

Moravcsik, E. A. (1969): Determination. In: Working Papers on Language Universals 1, 63-98. 
Muscetta, C. [1965] (1987): Giovanni Boccaccio e i novellieri. In: Cecchi, E. ; Sapegno, N. (eds.): Storia della Letteratura Italiana: Il Trecento. Milan, 323-569.

Orlandini, A. (1983): Une analyse sémantique et pragmatique des pronoms indéfinis en latin. In: Pinkster, H. (ed.): Latin Linguistics and Linguistic Theory. Proceedings of the $1^{\text {st International Colloquium on }}$ Latin Linguistics. Amsterdam, April 1981. Amsterdam/Philadelphia, 229-240.

Petronio, G. (1992): Geschichte der italienischen Literatur. Vol. I: Von den Anfängen bis zur Renaissance. Tübingen - Basel.

Primus, B. (1993): Word Order and Information Structure: A Performance-Based Account of Topic Positions and Focus Positions. In: Jacobs, J. ; von Stechow, A. ; Sternefeld, W. ; Vennemann, Th. (eds.): Syntax: Ein internationales Handbuch zeitgenössischer Forschung. Vol, I. Berlin - New York, 880-896.

Prince, E. F. (1981): Toward a Taxonomy of Given-New Information. In: Cole, P. (ed.): Radical Pragmatics. New York, 223-255.

Ramat, P. (1997): Why veruno means 'nobody'. In: Romance Philology 51-1, 1-124.

Renzi, L. (1976): Grammatica e storia dell'articolo italiano. In: Studi di grammatica italiana 5, 5-42.

Renzi, L. ( ${ }^{3} 1991$ ): L'articolo, in: Renzi, L. (ed.): Grande grammatica italiana di consultazione. Vol. I: La frase. I sintagmi nominale e preposizionale. Bologna, 357-423.

Rosén, H. (1994): The Definite Article in the Making, Nominal Constituent Order, and Related Phenomena. In: Herman, J. (ed.): Linguistic Studies on Latin. Selected Papers from the $6^{\text {th }}$ International Colloquium on Latin Linguistics (Budapest, 23-27 March 1991). Amsterdam/Philadelphia,129-150.

Selig, M. (1992): Die Entwicklung der Nominaldeterminanten im Spätlatein. Romanischer Sprachwandel und lateinische Schriftlichkeit. Tübingen.

Skrélina, L. ; Čebelis, D. (1972): La détermination du nom en ancien français. In: Romania 93, 289-302.

Stark, E. (1997): Voranstellungsstrukturen und topic-Markierung im Französischen. Mit einem Ausblick auf das Italienische. Tübingen.

Stark, E. (in press): Nominaldetermination, Textkohärenz und Übersetzungsvergleich - Signalisierung von Diskursreferenten in deutschen und italienischen Texten. In: Albrecht, J.; Gauger, H.-M, (eds.): Sprachvergleich und Übersetzungsvergleich. Akten der gleichnamigen Sektion des 26. Deutschen Romanistentages, Osnabrück 1999.

Tschida, A. (1995): Kontinuität und Progression. Entwurf einer Typologie sprachlicher Information am Beispiel des Französischen. Wilhelmsfeld.

Van Geenhoven, V. (1998): Semantic Incorporation and Indefinite Descriptions. Semantic and Syntactic Aspects of Noun Incorporation in West Greenlandic. Stanford.

Vater, H. (1982): Der 'unbestimmte Artikel' als Quantor. In: Welte, W. (ed.): Sprachtheorie und Angewandte Linguistik. Festschrift für Alfred Wollmann zum 60. Geburtstag. Tübingen, 67-74.

von Heusinger, K. (1997): Salienz und Referenz, Der Epsilonoperator in der Semantik der Nominalphrase und anaphorischer Pronomen. Berlin.

Yeom, J.-I. (1998): A Presuppositional Analysis of Specific Indefinites. Common Grounds as Structured Information States. New York - London. 